(reflected by pulse rate) are important predictors of the shift in blood pressure distribution observed when a low blood pressure community becomes urbanised. We would suggest that these same factors may play a part in at least the early stages of development of "essential hypertension."

This project was supported by the Wellcome Trust. We thank Clare Poulter and Jan Lury for fieldwork.

\footnotetext{
Kannel WB. Some lessons in cardiovascular epidemiology from Framingham. Am 7 Cardiol 1976:37:269-82.

2 Working Group on Arteriosclerosis of the National Heart, Lung and Blood Institute. Report of the working group on arteriosclerosis of the National Heart, L ung and Blood Institute. Bethesda: United States Department of Health and Human Services, Public Health Service, National Institutes of Health 1981: Vol 1, NIH No 81-2034; Vol 2, NIH No 81-0235.

3 Kannel WB, Neaton JD, Wentworth D, et al. Overall and coronary hear disease mortality rates in relation to major risk factors in 325348 men screened for the multiple risk factor intervention trial. A $m$ Heart 1986;112:825-36

4 Sinnett PF, Whyte HM. Epidemiological studies in a total highland population - Tukisenta, New Guinea: cardiovascular disease and relevant clinical electrocardiographic, radiologic and biochemical findings. I Chronic Dis 1973:26:265-9.

Truswell AS, Kennelly MB, Hansen JDL, Lee RB. Blood pressures of !kung bushmen in northern Botswana. Am Heart $f$ 1972;84:5-12.

6 Shaper AG, Wright DH, Kyobe J. Blood pressure and body build in three nomadic tribes of northern Kenya. East Afr Med f 1969;46:273-81.
not

7 Shaper AG, Leonard PJ, Jones KW, Jones M. Environmental effects on the body build, blood pressure and blood chemistry of nomadic warriors serving in the army in Kenya. East Afr Med f 1969;46:282-9.

8 Sever P, Gordon D, Peart WS, Beighton P. Blood pressure and its correlates in urban and tribal Africa. Lancet 1980;ii:60-4.

9 Cruz-Coke R, Etcheverry R, Nagel R. Influence of migration on blood pressure of Easter Islanders. Lancet 1964;i:697-9.

10 Sever PS, Poulter $N$. An hypothesis for the pathogenesis of essential hrpertension based on a new model of migration-induced blood pressure elevation. In: Hofman A, Grobbee DE, Schalekamp MADH, eds. Early pathogenesis of primary hypertension. Amsterdam: Elsevier, 1987. in Health 1984:38:181-6.
}

12 Poulter NR, Khaw KT, Sever PS. Higher blexd pressures of urban migrants from an African low blood pressure population are not due to selective migration. Am f Hypertens 1988;1:143-5S

13 Poulter NR, Lury J1), Thompson A. Blood pressures higher in the home than in the clinic in rural Kenya. F Eprdemiol Community Health 1986;40:186-7. 4 Medical Research Council Working Party. MRC trial of treatment of mild hypertension. Br.Med f 1985;291:97-104.

15 Rose G. Strategy of prevention: lessons from cardiovascular disease. Br Med 7 $1981 ; 282: 1847-51$

16 Meneely GR, Battarbee HD. High sodium-low potassium environment and hypertension. Am f Cardiol 1976;38:768-84.

17 Langford HG. Dietary potassium and hypertension: epidemiologic data. Ann Intern Med 1983;98:770-2.

18 Khaw KT, Rose G. Population study of blood pressure and associated factors in St Lucia, West Indies. Int F Epidemiol 1982;11:372-7.

19 Rikimaru T, Fujita Y, Okuda T, et al. Responses of sodium balance, blood pressure and other variables to sodium loading in Papua New Guinea pressure and other variables to sodium loditis
highlanders. Am f Clin Nutr 1988;47:502-8.

20 Scotch NA, Geiger JH. Epidemiology of essential hypertension: psychologic and socio-cultural factors in etiology. $\mathcal{F}$ Chronic Dis 1963;16:1183-21

21 Poulter NR, Shipley MJ, Bulpitt CJ, Markowe HJ, Marmot MG. Pulse rate and 24 hour urinary sodium content interact to determine blood pressure levels of male London civil servants. F Hypertens 1988;6 (suppl 4):611-3S.

22 Koepke JP, DiBona GF. High sodium intake enhances renal nerve and anti-natriuretic responses to stress in spontaneously hypertensive rats. Hypertension 1985;7:357-63.

23 Light KC, Koepke JP, Obrist PA, Willis PW. Psychological stress induces sodium and fluid retention in men at high risk for hypertension. Science 1983:220:429-31.

24 Intersalt Cooperative Research Group. Intersalt: an international study of electrolyte excretion and blood pressure. Results for 24 hour urinary sodium and potassium excretion. Br Med f 1988;297:319-28.

25 Straessen J, Bulpitt CJ, Thijs L, et al. Sympathetic tone and relation between sodium intake and blood pressure in the general population. Br Med $\mathcal{J}$ sodium intake an
1989:299:1502-3.

26 Folkow B, Grimby G, Thelesius $O$. Adaptive structural changes of the vascular walls in hypertension and their relation to the control of peripheral resistance. Acta Physiol Scand 1958; 44:255-72.

27 Lever AF. Slow pressor mechanisms in hypertension: a role for hypertrophy of resistance vessels? I Hypertens 1986;4:515-24.

28 Klatsky AL, Friedman GD, Seigelaub AB, Gerard MJ. Alcohol consumption and blood pressure: Kaiser-Permanente multiphasic health examination data. N Engl f Med 1977;296:1194-200.

29 Carvalho JJM, Baruzzi RG, Howard PF, et al. Blood pressure in 4 isolated small-village populations in the Intersalt study. Hypertension 1989;14:238-

(Accepted 15 fanuarv 1990)
Vascular Laboratories, St James's Hospital, PO Box 580, Dublin 8

Mary-Paula Colgan, MD, director

St George's Hospital, London

John A Dormandy, FRCS, consultant surgeon

Department of

Mathematics, University of Keele, Staffordshire

Peter W Jones, PHD, senior lecturer

Birch Hill Hospital, Rochdale, Lancashire Ivor G Schraibman, FRCS, consultant surgeon

Trinity College, Dublin D Gregor Shanik, FRCS, professor of vascular surgery

West Middlesex University Hospital, Isleworth, Middlesex

Richard A L Young, FRCS, consultant surgeon

Correspondence and requests for reprints to: Dr Colgan.

\title{
Oxpentifylline treatment of venous ulcers of the leg
}

Mary-Paula Colgan, John A Dormandy, Peter W Jones, Ivor G Schraibman, D Gregor Shanik, Richard A L Young

\section{Abstract}

Objective-To determine the effect of oxpentifylline on the healing of venous ulcers of the leg.

Design-Double blind, randomised, prospective, placebo controlled, parallel group study.

Setting-Four outpatient clinics treating leg ulcers in England and the Republic of Ireland.

Patients -80 Consecutive patients with clinical evidence of venous ulceration of the leg in whom appreciable arterial disease was excluded by the ratio of ankle to brachial systolic pressure being $>0 \cdot 8$.

Interventions-All patients received either oxpentifylline $400 \mathrm{mg}$ three times a day by mouth or a matching placebo for six months (or until their reference ulcer healed if this occurred sooner) in addition to a locally standardised method of compression bandaging.

Main outcome measures-The primary end point was complete healing of the reference ulcer within six months. The secondary end point was the change in the area of the ulcer over the six month observation period.

Results-Complete healing of the reference ulcer occurred in 23 of the 38 patients treated with oxpentifylline and in 12 of the 42 patients treated with a placebo. Life table analysis showed that the proportion of ulcers healed at six months was $64 \%$ in the group treated with oxpentifylline compared with $34 \%$ in the group treated with a placebo (log rank test $\chi^{2}=4.78, \mathbf{p}=0.03$ ), which was significant (odds ratio $=1 \cdot 81,95 \%$ confidence interval $1 \cdot 20$ to $2 \cdot 71$ ).

Conclusion-Oxpentifylline used in conjunction with compression bandaging improves the healing of venous ulcers of the leg.

\section{Introduction}

Venous ulcers of the leg are a common cause of illness in the community. The condition has a prevalence of $1 \%$, which is similar to that of diabetes, and it recurs chronically.' Ulcers of the leg are expensive to treat as they require regular dressing, often by district nurses. The cost to the NHS has been estimated to be $£ 1200$ for each unhealed ulcer a year. ${ }^{2}$ At present there is no proved pharmacological treatment, but this is not surprising as the pathophysiology of venous ulceration of the leg is poorly understood.

Two hypotheses have been advanced to explain the occurrence of venous ulcers of the leg in the context of the postphlebitic syndrome. ${ }^{34}$ The first hypothesis relates to the formation of a pericapillary cuff of fibrin, which acts as a barrier to diffusion and leads to local ischaemia of the tissues. ${ }^{56}$ The second hypothesis concerns the phenomenon of white cell trapping, which aggravates the trophic skin changes that are typically seen in patients with venous hypertension. ${ }^{\text {? }}$ Oxpentifylline (Trentai, Hoechst) has been found to have fibrinolytic effects ${ }^{9}$ and to influence the behaviour of white cells. ${ }^{10}$ It therefore seemed reasonable to study 
this drug in patients with venous ulceration of the leg.

\section{Patients and methods}

The trial design was a prospective, randomised, double blind, placebo controlled, parallel group study of 80 patients and was conducted in four centres in England and the Republic of Ireland. Consecutive eligible patients attending the leg ulcer clinic at each centre were randomised to receive either oxpentifylline (400 $\mathrm{mg}$ three times a day by mouth) or a matching placebo. Randomisation was performed in balanced blocks of eight with a separate list for each centre. Treatment was continued for six months or until the ulcer healed if this occurred sooner.

Patients with ulcers that had shown no signs of healing after at least two months of routine outpatient treatment were considered to be eligible for entry into the study, provided that the ulceration was clinically thought to be of venous origin, that the ratio of ankle to brachial systolic pressure was $>0 \cdot 8$, and that there was no contraindication to the prescription of oxpentifylline. ${ }^{11}$

The largest ulcer present was selected to be monitored as the reference ulcer for the duration of the study, provided that its diameter was between $2 \mathrm{~cm}$ and $15 \mathrm{~cm}$. At the initial visit the reference ulcer was traced with an indelible pen on to a transparent acetate sheet. ${ }^{12}$ The number of additional leg ulcers was also documented. Patients were seen every two weeks for six months and the reference ulcers were traced at alternate visits. An ulcer was considered to be healed only when complete re-epithelialisation had occurred.

Details of the dressings used in the four centres were recorded. Each centre used a two layer method of bandaging that was capable of producing adequate graduated compression. ${ }^{13}$ The bandaging method was standardised at each centre within the limits of clinical practice. All centres liaised closely with the local community or district nursing services to ensure continuity of the patients' dressings at home between study visits.

A computerised system was developed to measure the area of the ulcers from the tracing. (AUTOCAD software adapted by Datech, Orpington, Kent). All measurements were made by one trained observer, and the average of two readings was used for analysis.

Descriptive statistics were used to characterise the treatment groups at baseline. ${ }^{1+}$ The statistical methods included the $\chi^{2}$ test and the log rank test, which was used to compare the two treatment groups for overall healing of ulcers. The odds ratio was calculated for the rate of ulcer healing.

The trial was conducted in accordance with the Declaration of Helsinki (Venice amendment), and the protocol of the study was approved by the ethics committee at each centre. The informed consent of each patient was obtained in writing.

\section{Results}

Eighty patients were randomly allocated to receive either oxpentifylline or a placebo. Table I shows the characteristics of the patients in each treatment group at baseline. There were no differences between treatment groups or between centres, or between our patients and those surveyed in a recent epidemiological study of patients with leg ulcers. ${ }^{15}$ The patients were quite healthy for their age and were of good nutritional state, as indicated by body mass index and plasma albumin concentration. One patient in the placebo group was withdrawn from the study when a dermatologist diagnosed pemphigoid in an atypical ulcer.

Complete healing of the reference ulcer occurred in
23 of the 38 patients randomised to receive oxpentifylline and in 12 of the 42 patients randomised to receive a placebo. The results were analysed by the life table method, which gives the proportion of reference ulcers healed at each visit and takes account of the drop out rate. The results are shown in figure 1 . By the end of the study $64 \%$ of reference ulcers had healed in the patients treated with oxpentifylline, compared with $34 \%$ in those treated with a placebo $\left(\log\right.$ rank test $\chi^{2}{ }_{1}=$ $4.78, \mathrm{p}=0.03$; odds ratio $=1.81,95 \%$ confidence interval $1 \cdot 20$ to $2 \cdot 71$ ). This result was significant.

TABLE I-Characteristics of patients on entry to study. Values are means $(S D)$ unless stated otherwise

\begin{tabular}{|c|c|c|}
\hline \multirow[b]{2}{*}{ Characteristic } & \multicolumn{2}{|c|}{ Treatment group } \\
\hline & $\begin{array}{l}\text { Oxpentifylline } \\
(\mathbf{n}=38)\end{array}$ & $\begin{array}{l}\text { Placebo } \\
(n=42)\end{array}$ \\
\hline Age (years) & $71 \cdot 0(10)$ & $70 \cdot 2(9 \cdot 8)$ \\
\hline Sex ratio $(M: F)$ & $9: 29$ & $14: 28$ \\
\hline Height $(\mathrm{cm})$ & $166(11)$ & $166(11)$ \\
\hline Weight $(\mathrm{kg})$ & $74 \cdot 8(16)$ & $80 \cdot 6(21)$ \\
\hline Body mass index $\left(\mathrm{kg} / \mathrm{m}^{2}\right)$ & $26 \cdot 8(5 \cdot 3)$ & $29 \cdot 5(6 \cdot 8)$ \\
\hline No who smoked:never smoked & $22: 16$ & $26: 16$ \\
\hline $\begin{array}{l}\text { Onset of venous disease (years) } \\
\text { (median, IQR) }\end{array}$ & $17 \cdot 5(6 \cdot 5,31)$ & $18 \cdot 0(5,26)$ \\
\hline $\begin{array}{l}\text { Onset of present ulcer (months) } \\
\text { (median, IQR) }\end{array}$ & $6(3,13)$ & $9(4,13)$ \\
\hline $\begin{array}{l}\text { No with history of varicose veins or } \\
\text { phlebitis }\end{array}$ & 30 & 30 \\
\hline Ankle index & $1.05(0 \cdot 13)$ & $1 \cdot 06(0 \cdot 14)$ \\
\hline Albumin $(\mathrm{g} / \mathrm{l})($ median, IQR) & $40 \cdot 3(38,43)$ & $40 \cdot 6(38,43)$ \\
\hline Ulcer area $\left(\mathrm{cm}^{\prime}\right)($ median, IQR $)$ & $5 \cdot 2(3 \cdot 1,9 \cdot 5)$ & $4 \cdot 7(2 \cdot 7,11 \cdot 4)$ \\
\hline No without other ulcers & 20 & 18 \\
\hline No with other ulcers & 18 & 24 \\
\hline
\end{tabular}

$\mathrm{IQR}=$ Interquartile range.

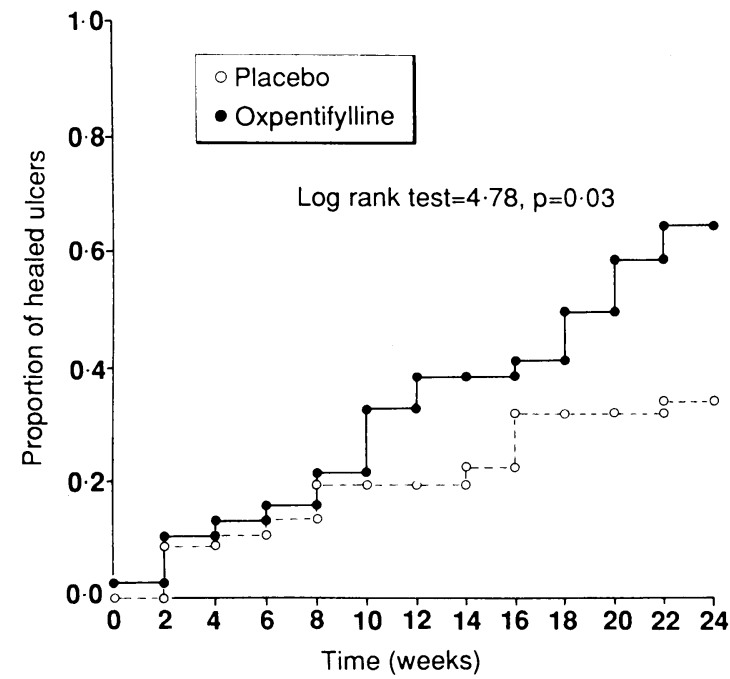

FIG 1-Life table analysis of proportion of ulcers healed at each visi

Many of the patients had additional ulcers at the start of the study (table I). These additional ulcers were monitored to see whether they had healed by the time the reference ulcer had healed. In only two patients (one in each treatment group) was an additional ulcer still present after the reference ulcer had healed. In the patient who received a placebo the persistent additional ulcer developed anew during the course of the study.

The area of the reference ulcer was calculated from the tracings made at alternate follow up visits. The median area of the ulcer for each treatment group at each follow up visit was studied so that information could be gained about the progress of the reference ulcer apart from its complete healing. These results are presented in figure 2, which shows a consistent improvement in the area of the ulcers in the patients receiving oxpentifylline compared with a variable outcome in those receiving a placebo. A reduction in the area of the reference ulcer at the final visit relative 
to baseline was seen in 35 of the 38 patients receiving oxypentifylline compared with 26 of the 42 patients receiving a placebo $\left(\chi^{2}=10 \cdot 0, p=0 \cdot 002\right)$.

The tolerability of the treatment was studied. Unwanted effects were comparable between the two treatment groups, with 17 of the 38 patients (45\%) who received oxpentifylline and 14 of the 42 patients (33\%) who received a placebo complaining of side effects $\left(\chi_{1}^{2}=1 \cdot 1, p=0 \cdot 30\right)$. There was an excess of drop outs in the group treated with a placebo $(9 / 42(21 \%))$ compared with the group treated with oxpentifylline $(3 / 38$ $(8 \%))$, but this difference was not significant $\left(\chi_{1}{ }_{1}=2 \cdot 9\right.$, $\mathrm{p}=0.09)$. Most of the drop outs occurred early in the study, but in only one of these patients was there evidence of a reduction in the area of the ulcer. This particular patient was receiving oxpentifylline. The three patients taking oxpentifylline who withdrew from the study did so because of oedema and depression, vomiting, and dyspepsia and diarrhoea. Seven of the patients taking placebo withdrew because of purpura, skin rash, dizziness, diarrhoea (two patients), cellulitis and pain, and headache and nausea; the two others dropped out because of poor compliance and because an ulcer was diagnosed as pemphigoid. The unwanted effects described are listed in table II. The

TABLE II - Unwanted effects of oxpentifylline and placebo classified by type. Values are numbers of complaints

\begin{tabular}{lcc}
\hline Type of complaint & Oxpentifylline & Placebo \\
\hline System affected: & & \\
$\quad$ Central nervous & 7 & 5 \\
$\quad$ Respiratory & 3 & 1 \\
$\quad$ Cardiovascular & 2 & 6 \\
$\quad$ Gastrointestinal & 7 & 4 \\
$\quad$ Genitourinary & 1 & 3 \\
Skin & 1 & 3 \\
Infection & 2 & \\
Pain & 2 & 22 \\
Unspecified & 1 & 2 \\
\hline Total & 26 & \\
\hline
\end{tabular}

discrepancy between the incidence of adverse events and the incidence of drop out for each treatment group suggests that other factors, such as failure of the ulcer to respond, rather than the treatment itself might have been responsible for patients dropping out of the study.

Possible confounding factors were studied to see whether these had any effect on the healing of ulcers. The dressing and bandaging methods used were compared between the treatment groups but no differences were found. The effects of centre, the size of the ulcer at baseline, the length of history of venous disease, the duration of the current episode of disease, and the type of conservative treatment used were all studied for possible interactions with healing. No such interactions were detected.

\section{Discussion}

We have confirmed a report that oxpentifylline might be effective in healing venous ulcers of the leg when added to a regimen of compression bandaging. ${ }^{16}$ The effect of different dressings on the healing of ulcers has been the subject of extensive research, but few of the studies have been properly controlled. A review of the subject found little evidence to show that particular dressings made any difference to healing rates. ${ }^{17}$ High healing rates have recently been reported with a four layer compression bandaging method on its own, ${ }^{18}$ but this study had an unusual design and used historical controls. The value of adequate two layer compression bandaging is well established. ${ }^{13}$

Although pharmacological treatment has been advocated for the healing of venous ulcers, the few studies

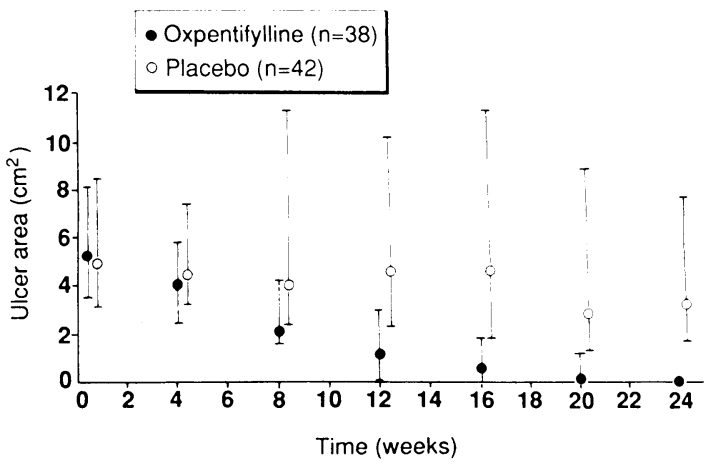

FIG 2-Ulcer area at each visit. Values are medians with $95 \%$ confidence intervals

that have been placebo controlled have had design problems. Their shortcomings have included inadequate numbers of patients, ${ }^{19-21}$ crossover design, ${ }^{2021}$ and end points other than complete healing of the ulcer. ${ }^{16}{ }^{1920} \mathrm{~A}$ well designed study of rutosides showed no effect on the healing of ulcers. ${ }^{22}$ Two studies using profibrinolytic agents have yielded conflicting results. A study of defibrotide showed some effect on the healing of ulcers but was of crossover design, ${ }^{21}$ whereas a large controlled trial found that stanozolol was ineffective in promoting the healing of venous ulcers (A D R Northeast et al, venous forum meeting, Manchester, 1989). Studies of the bacteriology of leg ulcers suggest that the role of antibiotics and antiseptics in promoting healing is limited to those with frank infection. ${ }^{23}$

The haemorrheological properties of oxpentifylline have been widely studied and described. ${ }^{24}$ Of particular interest in the context of our study are the properties of the compound with regard to the pathophysiology of venous ulcers. Oxpentifylline improves the delivery of oxygen in ischaemic tissues, ${ }^{25}$ has fibrinolytic effects ${ }^{26}$ that are possibly mediated by leucocytes, ${ }^{27}$ and reduces the adhesion of polymorphonuclear leucocytes. ${ }^{28}$ These properties might explain the clinical benefit of oxpentifylline seen in our study.

We conclude that the healing rates of venous ulcers of the leg will be increased appreciably by the addition of oxpentifylline to a standard regimen of dressing and compression bandaging.

The study nurses and technicians were Mrs $\mathrm{J}$ Moller (London), Mrs T Kelly (London), Mr D Metoo (Rochdale), and $\mathrm{Mr}$ S Stanley (Dublin). We acknowledge the advice and help of Drs S Allen and M Sugrue and the administrative support provided by Hoechst UK Limited.

1 Callam MJ, Ruckley CV, Harper DR, Dale JJ. Chronic ulceration of the leg: extent of the problem and provision of care. BrMed f 1985;290: 1855-6.

2 Harkiss $\mathrm{KJ}$. Cost analysis of dressing materials used in venous leg ulcers. Pharmacy fournal 1985;235:268-9.

3 Browse NL. Venous ulceration. Br Med f 1983;286: 1920-2.

4 Hobbs JT. The post thrombotic syndrome. Scott Med $\mathcal{F}$ 1978;23:323-4. Browse NL, Burnand KG. The cause of venous ulceration. Lancel 1982;ii: 243-5.

6 Burnand KG, Whimster I, Naidoo A, Browse NL. Pericapillary fibrin in the ulcer-bearing skin of the leg: the cause of lipodermatosclerosis and venous ulcer-bearing skin of the leg: the cause

7 Coleridge-Smith PD, Thomas P, Scurr JH, Dormandy JA. Causes of venous ulceration: a new hypothesis. Br Med f 1988;296:1726-7.

8 Thomas PRS, Nash GB, Dormandv JA. White cell accumulation in dependent legs of patients with venous hypertension: a possible mechanism for trophic changes in the skin. Br Med $\mathcal{f} 1988 ; 296: 1693-5$.

9 Jarrett PEM, Moreland M, Browse NL. The effect of oxpentifylline ('Trental') on fibrinolytic activity and plasma fibrinogen levels. Curr Med Res Opin 1977; 4:492-5.

10 Matrai A, Ernst E. Pentoxifylline improves white cell rheology in claudicants. Clinical Hemorrheolog $y$ 1985;5:483-91.

11 Anonymous. ABPI data sheet compendium 1986-87. London: Datapharm Publications, 1986.

12 Allen S. A simple technique for recording varicose ulcers. Practitioner 1967;199:97-9.

13 Tennant WG, Park KGM, Ruckley CV. Testing compression bandages. Phlebology 1988;3:55-61.

14 Armitage P, Berry G. Statistical methods in medical research. Oxford: Blackwell Scientific, 1987.

15 Callam MJ, Harper DR, Dale JJ, Ruckley CV. Chronic ulcer of the leg: clinical history. Br Med F 1987;294:1389-91. 
16 Weitgasser $\mathrm{H}$. The use of pentoxifylline "Trental 400 , in the treatment of leg ulcers: results of a double-blind trial. P'harmatherapeutica 1983;3 suppl $1: 1+3-51$.

17 Anonymous. Dressings for leg ulcers. Drug Ther Bull 1986;24:9-12.

18 Blair SD, Wright DIDI, Backhouse CM, Riddle E, McCollum CN. Sustained compression and healing of chronic venous ulcers. Br Med f 1988:297: $1159-61$.

19 Arenas R, Atoche C. Post-thrombotic leg ulcers: safety and efficacy of treat ment with pentoxifylline (double-blind study in 30 patients). Dermatologica. ment with pentoxifylline double-blind study in 30

20 Levh F. Therapic des Ulcus cruris venosum mit Mäusedornextrakt und Trimethrlhesperidinchalkon. Therapiewoche 1988:38:2325-31.

21 Belcaro $\mathrm{G}$, Marelli $\mathrm{C}$. Treatment of venous lipodermatosclerosis and ulceration in venous hypertension by elastic compression and fibrinolytic enhancement with defibrotide. Phlebology 1989;4:91-106.

22 Mann RJ. A double blind trial of oral $O, 6$-hydroxyethyl rutosides for statis leg ulcers. Br f Clin Pract 1981;35:79-81.

23 Schraibman IG. The bacteriology of leg ulcers. Phlebology 1987;2:265-70.

24 Ward A, Clissold SP. Pentoxifylline: a review of its pharmacodynamic and pharmacokinetic properties, and its therapeutic efficacy. Drugs 1987;34 $50-97$

25 James DR, Holland BM, Hughes MR, Jones JG, Wardrop CAJ. Oxpentifvlline: effects on red cell deformability and oxvgen availability from the blood in intermittent claudication. Clinical Hemorrheologv 1984:4:525-31.

26 Angelkort B, Kiesewetter $\mathrm{H}$. Influence of risk factors and coagulation phenomena on the fluidity of blood in chronic arterial occlusive disease. Scand f Clin Lab Invest 1984;41/suppl 156):185-8.

27 Knox P Lelocyte-mediated activation of the fbrinolyeic parhway and the

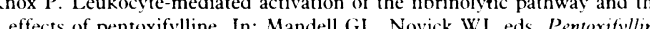
ence Pharmaceuticals, 1988:96-104.

28 Bertocchi F, Proserpio P, Lampugnani MG, Dejana E. The effect of pentoxifylline on polymorphonuclear cell adhesion to cultured endothelia cells. A preliminary report. In: Mandell GL, Novick WJ, eds. Pentoxifyllin and leukocyte function. Somerville, New Jersey: Hoechst-Roussel Pharmaceuticals, 1988:68-74.

Accepted 15 fanuary 1990

\title{
Relation between dose of bendrofluazide, antihypertensive effect, and adverse biochemical effects
}

\author{
Jan E Carlsen, Lars Køber, Christian Torp-Pedersen, Peter Johansen
}

Abstract

Objective-To determine the relevant dose of bendrofluazide for treating mild to moderate hypertension.

Design-Double blind parallel group trial of patients who were given placebo for six weeks and then randomly allocated to various doses of bendrofluazide $(1 \cdot 25,2 \cdot 5,5$, or $10 \mathrm{mg}$ daily $)$ or placebo for 12 weeks.

Setting-General practices in Zealand, Denmark.

Patients - 257 Patients with newly diagnosed or previously treated hypertension, aged $25-70$, who had a mean diastolic blood pressure of $100-120 \mathrm{~mm}$ $\mathrm{Hg}$ after receiving placebo for six weeks.

Main outcome measures-Reduction in diastolic blood pressure and changes in biochemical variables (potassium, urate, glucose, fructosamine, total cholesterol, apolipoprotein A I, apolipoprotein B, and triglyceride concentrations).

Results - All doses of bendrofluazide significantly reduced diastolic blood pressure to the same degree $(10-11 \mathrm{~mm} \mathrm{Hg})$. Clear relations between dose and effect were shown for potassium, urate, glucose, total cholesterol, and apolipoprotein B concentrations. The $1.25 \mathrm{mg}$ dose increased only urate concentrations, whereas the $10 \mathrm{mg}$ dose affected all the above biochemical variables.

Conclusion-The relevant range of doses of bendrofluazide to treat mild to moderate hypertension is $\mathbf{1} \cdot \mathbf{2 5}-\mathbf{2} \cdot 5 \mathrm{mg}$ a day. Higher doses caused more pronounced adverse biochemical effects including adverse lipid effects. Previous trials with bendrofluazide have used too high doses.

Medicon, Svanemøllevej 2, DK-2100, København $\emptyset$, Denmark

Jan E Carlsen, MD, senior lecturer

Lars Køber, MD, resident Christian Torp-Pedersen, $\mathrm{MD}$, senior lecturer

Leo Pharmaceutical Products, Industriparken, DK-2750, Ballerup, Denmark

Peter Johansen, PHD, medical adviser

Correspondence to:

Dr Carlsen.

$\operatorname{Br} \operatorname{Med} \mathcal{f} 1990 ; 300: 975-8$ fluazide $(10 \mathrm{mg} /$ day $)$ or a titrated dose of propranolo with placebo. ' 2 There was no basis for choosing a dose of $10 \mathrm{mg}$ bendrofluazide.

We investigated the relevant dose range of bendro- fluazide for treating mild to moderate arterial hypertension as this could affect both the choice and outcome of treatment.

\section{Methods}

Selection of patients--Patients aged 25-70 presenting to general practices in Zealand, Denmark, with newly diagnosed or previously treated arterial hypertension (up to two drugs) who gave informed consent were eligible for the study.

Patients were excluded if they were pregnant or lactating; had had a myocardial infarction or stroke within the past six months; had angina pectoris; were being treated for heart failure, gout, or uncontrolled diabetes mellitus or with drugs that reduced lipid concentrations; were intolerant of bendrofluazide; had reduced kidney function (creatinine concentration $>150 \mu \mathrm{mol} / \mathrm{l}$ ); did not take $80-120 \%$ of the prescribed tablets while receiving a placebo at the start of the study.

Study design-Patients whose blood pressure was between 100 and $120 \mathrm{~mm} \mathrm{Hg}$ after they had taken placebo for six weeks were randomly allocated in blocks of 10 on a double blind basis to receive placebo or bendrofluazide at a dose of $1 \cdot 25,2 \cdot 5,5$, or 10 mg a day. Randomisation was performed from a list of computer generated numbers. The $10 \mathrm{mg}$ dose was chosen because this was used in the Medical Research Council's trial and the 2.5 and $5 \mathrm{mg}$ doses because they are recommended by the joint national committee on detection, evaluation, and treatment of high blood pressure. ${ }^{3}$ The dose of $1.25 \mathrm{mg}$ was believed to represent a point on the lower part of the dose-response curve. The active tablets contained $573 \mathrm{mg}$ potassium chloride and either $1.25 \mathrm{mg}$ or $2.5 \mathrm{mg}$ bendrofluazide (Centyl K, Leo Pharmaceutical Products). Placebo and active tablets were identical in appearance and taste. All patients received four tablets daily, two in the morning and two at lunch. Those receiving fewer than four active tablets daily were given the active tablets in the morning. Patients were assessed on an outpatient basis for four, 10, and 12 weeks after randomisation. Biochemical variables were measured before randomisation and at the end of the study; these variables included total cholesterol, apolipoprotein A I, apolipoprotein B, sodium, potassium, glucose, fructosamine, urate, and creatinine concentrations. The study was approved by the local ethical committee.

Methods of assessment-The patient's blood pressures were measured twice, in the sitting position after five 